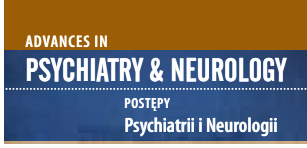

Correspondence to/Adres do korespondencji:

Marcin Górniak

Department of Adult Psychiatry

Poznan University of Medical Sciences

27/33 Szpitalna St.

60-572 Poznan, Poland

e-mail: marcin_gorniak@o2.pl

Submitted/Otrzymano: 15.03 .2021

Accepted/Przyjęto do druku: 06.06.2021

\section{The influence of Nordic walking on the general functioning and cognitive performance of patients with Alzheimer's disease} Wpływ aktywności typu nordic walking na funkcjonowanie ogólne i sprawność poznawczą pacjentów z chorobą Alzheimera

\author{
Marcin Górniak (D), Filip Rybakowski (D), Jan Jaracz (D), \\ Janusz Rybakowski iD
}

Department of Adult Psychiatry, Poznan University of Medical Sciences, Poznan, Poland

\begin{abstract}
Purpose: Most studies show that physical activity (PA) can inhibit the progression of Alzheimer's disease (AD). This research aimed to investigate the effect of 3-month moderate PA on the general functioning and cognitive abilities of AD patients.

Methods: The study included 32 patients with mild or moderate AD who scored 11-23 points in Mini-Mental State Examination (MMSE). Half of the participants were qualified to perform the exercises; the other half constituted the control group. The recommended form of activity was Nordic walking, 30 minutes, 3 days a week, for 3 months, under the supervision of the patient's carer. General functioning and the severity of cognitive deficits were assessed using the Activities of Daily Living (ADL) scale and the Montreal Cognitive Assessment scale (MoCA) before and after the 3-month study.

Results: No improvement was observed in the overall functioning of the patients after 3 months of regular, moderate PA. Neither were there any differences in this respect between the active and inactive groups, both in patients with mild (MMSE 19-23) and moderate (MMSE 11-18) disease severity. Men showed a deterioration in overall functioning regardless of PA. No differences in cognitive functioning were observed between the active and inactive groups, the two genders or between mild (MMSE 19-23) and moderate (MMSE 11-18) subjects.
\end{abstract}

Conclusions: The 3-month, moderate, Nordic walking PA did not improve the overall general functioning or cognitive performance in patients with mild or moderate AD.

Key words: Alzheimer's disease, physical activity, Nordic walking, Activities of Daily Living scale, Montreal Cognitive Assessment scale.

\title{
Streszczenie
}

Cel: Wyniki większości badań wskazują, że aktywność fizyczna (AF) może hamować postęp choroby Alzheimera (chA). Celem prezentowanej pracy było zbadanie wpływu trzymiesięcznej umiarkowanej AF na ogólne funkcjonowanie i zdolności poznawcze u pacjentów $\mathrm{z}$ chA.

Metody: Badaniem objęto 32 pacjentów z łagodną lub umiarkowaną chA [wynik w Mini-Mental State Examination (MMSE) w zakresie 11-23 punktów]. Połowę uczestników zakwalifikowano do wykonywania ćwiczeń, druga połowa stanowiła grupę kontrolną. Zalecaną formą aktywności był nordic walking w wymiarze 30 minut, 3 dni w tygodniu, przez 3 miesiące, pod nadzorem opiekuna. Oceniano funkcjonowanie ogólne i nasilenie deficytów poznawczych za pomocą skali Activities of Daily Living (ADL, Skala aktywności dnia codziennego) oraz Montreal Cognitive Assessment (MoCA, Montrealska skala oceny funkcji poznawczych) przed i po 3 miesiącach badania.

Wyniki: Nie stwierdzono poprawy w ogólnym funkcjonowaniu pacjentów po 3 miesiącach regularnej, umiarkowanej PA. Nie wykazano w tym zakresie różnic między grupą aktywną i nieaktywną zarówno u pacjentów z łagodnym (MMSE 19-23), jak i umiarkowanym (MMSE 11-18) nasileniem choroby. Mężczyźni wykazywali pogorszenie ogólnego funkcjonowania niezależnie od PA. 
The influence of Nordic walking on the general functioning and cognitive performance of patients with Alzheimer's disease

Wpływ aktywności typu nordic walking na funkcjonowanie ogólne i sprawność poznawcza pacjentów z chorobą Alzheimera

Nie zaobserwowano różnic między grupami aktywną i nieaktywną w funkcjonowaniu poznawczym u obu płci oraz u osób o łagodnym (MMSE 19-23) i umiarkowanym (MMSE 11-18) nasileniu.

Wnioski: Trzymiesięczna, umiarkowana AF w formie nordic walking nie poprawiła funkcjonowania ogólnego ani sprawności poznawczej u pacjentów $\mathrm{z}$ łagodną lub umiarkowaną postacią chA.

Słowa kluczowe: choroba Alzheimera, aktywność fizyczna, nordic walking, Skala aktywności dnia codziennego, Montrealska skala oceny funkcji poznawczych.

\section{INTRODUCTION}

Worldwide, more than 25 million people are currently affected by dementia, most of them suffering from Alzheimer's disease (AD). The affected population constitutes a growing global health problem with significant negative consequences for individuals and society. Despite progress in the pharmacological treatment of $\mathrm{AD}$, the prognosis is generally poor. The disease inevitably leads to marked disability, dependence, and finally death. Therefore, much attention has been paid in recent decades to the development of novel medications and the introduction of other non-pharmacological interventions.

It is generally agreed that physical activity (PA) plays a role in the prevention of many medical conditions and mental diseases. It has been postulated that different forms of physical exercises may prevent, alleviate, or at least delay the progression of AD. Numerous studies assessing the relationship between $\mathrm{PA}$ and $\mathrm{AD}$ have been published in the last two decades, but their results are still inconclusive.

The effect of PA on the cognitive functioning of people with $\mathrm{AD}$ was the aim of the meta-analysis conducted by Heyn et al. [1]. Thirty randomized trials, which included 2020 subjects with cognitive impairment $($ MMSE $<25)$, aged 65 and over, who participated in at least 4 weeks of training were analyzed. The authors demonstrated a positive effect of exercise on cognition, exercise capacity, and behavioral disorders accompanying dementia. Another systematic review and meta-analysis of $13(n=869)$ randomized controlled trials (RCTs) have also provided evidence for a positive effect of exercise on the cognitive function of patients with $\mathrm{AD}$ [2]. These findings were confirmed by the authors of a more recent meta-analysis [3] which included 13 randomized controlled trials $(n=673)$.

Authors of another meta-analysis [4] found that in comparison to drug treatment (cholinesterase inhibitors, Memantine, and Ginkgo biloba) which had a small, pooled effect on cognition of $\mathrm{AD}$ patients and people with mild cognitive impairment (MCI), exercise training resulted in moderate to strong pooled effect size in $\mathrm{AD}$ patients.

Many risk factors and protective factors have been linked with the pathogenesis of $\mathrm{AD}$. In this context, the goal of another interesting line of research is to ex- plore whether PA can decrease the risk of AD. Results of a meta-analysis published by Santos-Lozano [5] based on 10 high-quality studies $(N=23345)$ suggest that despite the limitations related to the quality of the obtained data, a regular PA may play a protective role in case of the elderly. However, the role of PA should be considered in the context of other protective factors. The aim of a systematic review and meta-analysis of 243 observational prospective studies and 153 randomized controlled trials was to assess the potential role of 104 modifiable factors and 11 interventions in AD protection [6]. The authors found 19 potentially protective factors among them 10 (i.a. education, cognitive activity, high body mass index in late life, hyperhomocysteinemia, depression) were recognized as Level A (strong evidence) while physical exercise was found as Level B (weaker evidence) together with i.a.: obesity in midlife, weight loss in late life, smoking, sleep, cerebrovascular disease.

It turns out, however, that the relationship between PA and $\mathrm{AD}$ is probably more complex. A 28 -year observational study [7], in which the physical activity of 10,308 people was assessed every four years, in parallel with the monitoring of their cognitive functions showed that nine years before the diagnosis of dementia, a gradual decline in PA began - regardless (!) of its initial level. From that perspective, a reduction in PA may be considered rather as a prodrome of dementia than a risk factor for the disease.

In contrast, other studies cast doubt on the importance of PA as a protective agent for dementia. Tan et al. [8] reviewed data on a potential relationship between PA and risk of dementia collected in the Framingham study. During a 10-year follow-up of 2,063 subjects, the authors found that even mild PA was associated with a lower risk of being diagnosed with dementia, but this was not the case for people with the APOE- $\varepsilon 4$ genotype. These data imply a linear relationship between PA in old age and the volume of the hippocampus. However, extending the follow-up to 22 years reduced the relationship between PA and the risk of $\mathrm{AD}$. The results of other meta-analyses [9-11] also question the importance of the protective effect of PA. A metaanalysis by Frederiksen et al. [12] showed that there is no evidence that PA affects the volume of the hippocampus, $A \beta$ accumulation, and the concentration of tau protein in the cerebrospinal fluid. A one-year controlled study by 
Lamb et al. [13] included 494 subjects (65\% men) with mild to moderate dementia. Some of them $(n=329)$ were assigned to the group taking moderate or high-level PA while the other participants were provided with standard care. In the active group, a slight but statistically significant faster progression of the disease was demonstrated. Moreover, no improvement in the results obtained with the Alzheimer's Disease Cooperative Study - Activity of Daily Living scale (ADL) was found.

Many methodological problems of studies focused on the impact of PA on AD patients were raised by their authors, including heterogeneity of the types of physical activity or exercise, the methods and duration of interventions, its intensity, and methods of assessment of cognition. Small sample sizes and lack of RCT were also considered in this context.

The following hypotheses were adopted:

1. Regular physical activity will improve the overall functioning of patients, hinder the process of deterioration or slow down its rate.

2. Taking regular physical activity will improve cognitive functioning of patients, inhibit the process of deterioration or slow down its pace.

\section{METHODS}

The study was a quasi-experiment: it was the patients and their carers who decided to participate actively or passively in the study. After getting acquainted with its course, the patient and the carer who agreed to participate signed a written consent. The consent for the study was approved by the Bioethics Committee of the Medical University of Karol Marcinkowski in Poznań (decision no. 45/15 of 8 January 2015).

Outpatients from the Polish population who met the diagnostic criteria for probable $\mathrm{AD}$ according to ICD-10 (International Statistical Classification of Diseases, version 10) with mild to moderate severity (MMSE 11-23) were recruited for the study. The drugs used to treat the patients (Donepezil, Rivastigmine, Memantine) were taken by them in stable doses for at least 3 months prior to the beginning of the study. Another inclusion criterion was a declaration of help in conducting the study by the patient's caregiver. Among the exclusion criteria were depression, significant somatic contraindications to $\mathrm{PA}$, and a physically active lifestyle before the study. Of the 36 people who agreed to participate in the study, 31 passed all the protocol-defined testing procedures (one in 32 dropped out before the follow-up testing). 27 study participants suffered from late-onset $\mathrm{AD}$ (LOAD), 5 from early-onset $\mathrm{AD}$ (EOAD). This was the basis for distinguishing subgroups in the study, along with the participant's gender and the stage of the disease. Finally, 16 out of 19 people (including 3 men) who initially declared active participation in the study were qualified to the active group. The training intensity in the first month was meant to be just a warmup for the next 2 months of regular, moderate PA. Nordic walking was the recommended form of activity. It is performed with purpose-designed walking poles similar to ski sticks. Both Nordic walking and conventional walking are beneficial for older adults. However, compared to conventional walking, Nordic walking provides additional benefits, such as improving aerobic capacity and muscular strength as well as other components of functional fitness in a short period. Nordic walkers use more of their entire body and receive fitness building stimulation for the chest, upper extremities, abdominals, spinal, and other core muscles, which is absent from normal walking, The tutor, who was a living-in family member of the patient in most cases, supervised the duration, intensity and regularity of PA, following the guidelines received from the researchers. Based on the results of studies conducted by other researchers $[14,15]$, the minimum PA in the second and third month was adopted as the criterion for qualifying the patient to the active group at 30 minutes three times a week. The primary treatment for $\mathrm{AD}$ was not modified during the study. Daily activity and the severity of cognitive impairment were assessed at the beginning of the study and 3 months after its completion.

\section{Psychometric measurements}

When qualifying the potential candidates for the study, the previously obtained results in the Mental State Assessment Short Scale (MMSE) were used. This scale was not reused during the study.

\section{Activities of Daily Living (ADL)}

General functioning was assessed using Activities of Daily Living scale [16], which is a questionnaire that allows for a precise assessment of the degree of independence and efficiency of patients, based on information obtained from the caregiver. The assessment covers the patient's daily activities over the past month. A non-disabled person scores 78 points. It usually takes 10 to 15 minutes to conduct the interview necessary to complete the questionnaire.

\section{Montreal Cognitive Assessment scale (MoCA)}

The severity of cognitive deficits was assessed with the use of the Montreal Cognitive Assessment scale [17, 18], which assesses the following cognitive functions: orientation, visuo-spatial abilities, executive, short-term memory, verbal fluency, attention, and abstraction. It takes 10 to 15 minutes to complete the MoCA test, which in the current study was performed twice: at the beginning and the end of the study, using two different, equivalent versions to eliminate the measurement error resulting from learning. 
The influence of Nordic walking on the general functioning and cognitive performance of patients with Alzheimer's disease Wpływ aktywności typu nordic walking na funkcjonowanie ogólne i sprawność poznawcza pacjentów z chorobą Alzheimera

\section{Statistical analysis}

The Shapiro-Wilk test was used to determine whether the data could be approximated by a normal distribution, and the Bartlett test to determine the homoscedasticity of variance (equality of variance between groups). As only a small number of features showed a normal distribution, it was decided to apply the non-parametric methods of statistical inference. To compare the data at the start and end of the study in the active and passive groups, the Wilcoxon test was applied to the paired data, while the comparison of the active and passive groups was performed using the Mann-Whitney test. The test power (probability of rejecting the null hypothesis if false) calculated using GPower (version 3.1) is given in parentheses for each significance value. Correlation analysis was performed using the Spearman correlation method, while in the case of the correlation coefficient significance test, a multiple test correction was applied. In all statistical tests, the level of significance was $\alpha<0.05$.

\section{RESULTS}

\section{Demographic and clinical characteristics of patients}

As can be seen from the data in the Table 1, there are no differences between the active and passive groups in terms of clinical or demographic characteristics. The only difference was in education: in the active group, four people had higher education; there were no such people in the inactive group, while four more people had primary education in this group.

\section{The influence of physical activity on general functioning - ADL scale}

There were no statistically significant differences between the ADL measurements at the beginning and at the end of the study, both in the entire study population and in the active and inactive groups, and in the case of the initial severity of cognitive deficits (MMSE score) as an additional criterion (Figure I). Taking into account both the activity and gender of the patients, the ADL scale showed statistically significant deterioration in all men (active and inactive) (Wilcoxon test, $p=0.035$, test power $47 \%$ ).

In the group of patients with the LOAD $(N=27)$, no statistically significant differences were found between ADL measurements at the beginning and the end of the study, also when divided into the active and inactive group. Taking into account the additional criteria for the division of this group - the activity and gender of patients - statistically significant deterioration was found in all men (active and inactive; Wilcoxon test, $p=0.035$, test power $47 \%$ ).

\section{The influence of physical activity on cognitive functions - MoCA scale}

There were no statistically significant differences between the MoCA measurements at the beginning and the end of the study in the active and passive groups (Wilcoxon test $p=0.140$ and $p=0.470$, test power 27\% and $16 \%$, respectively) (Figure II). Taking into account the criteria of gender and physical activity also did not allow for finding statistically significant differences between the results obtained by the groups at the beginning and the end of the study.

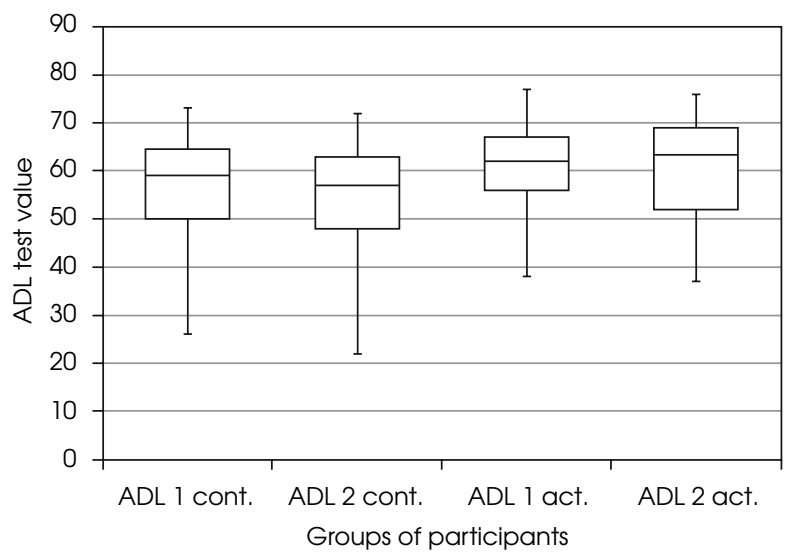

Figure I. The effect of physical activity on general functioning - ADL scale (The Alzheimer's Disease Cooperative Study - Activities of Daily Living). ADL1 act. - score of active participants in the ADL scale before training, ADL2 act. - score of active participants in the ADL scale after 3-month of training, ADL1 cont. - score of non-active participants in the ADL scale at the beginning of the study, ADL2 cont. - score of non-active participants in the ADL scale after 3 months

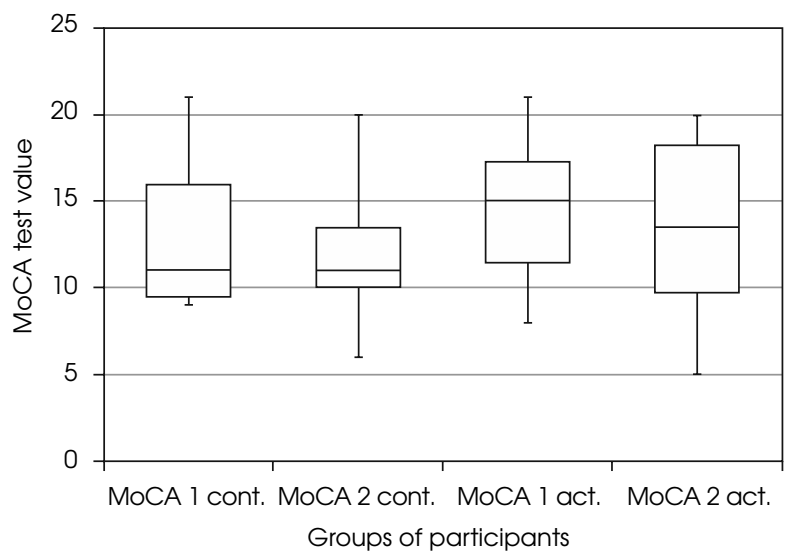

Figure II. The effect of physical activity on cognitive functions - MoCA scale (Montreal Cognitive Assessment scale). MoCAl act. - score of active participants in MoCA scale before training, MoCA2 act. - score of active participants on the MoCA scale after 3-month training. MoCAl cont. - score of non-active participants in the MoCA scale at the beginning of the study, MoCA2 cont. - score of inactive participants in the MoCA scale after 3 months 
Table 1. Demographic and clinical characteristics of patients

\begin{tabular}{|c|c|c|c|}
\hline Factor & Total & Non-active & Active \\
\hline$n$ & 32 & 16 & 16 \\
\hline Age & M: 77.4, SD: 7.2, Me: 78 & M: 79.0, SD: 7.0, Me: 78.5 & M: 75.7, SD: 7.2, Me: 78 \\
\hline Age of AD onset (years) & M: 70.6, SD: 5.9, Me: 70.5 & M: 71.7, SD: 5.85, Me: 72 & M: 69.5, SD: 6, Me: 70 \\
\hline AD duration (years) & M: 6.7, SD: 2.2, Me: 6 & M: 7.2, SD: 2.2, Me: 7.5 & M: 6.2, SD: 2, Me: 6 \\
\hline MMSE & Me: $18(16-21)$ & Me: 18 (15-20) & Me: $18(17-21)$ \\
\hline MMSE 19-23 & 15 & 8 & 7 \\
\hline MMSE 11-18 & 17 & 8 & 9 \\
\hline Early onset AD & 5 & 2 & 3 \\
\hline Late onset AD & 27 & 14 & 13 \\
\hline Women $(n)$ & 26 & 13 & 13 \\
\hline $\operatorname{Men}(n)$ & 6 & 3 & 3 \\
\hline Treated with Donepezil & 22 & 9 & 13 \\
\hline Treated with Rivastigmine & 10 & 7 & 3 \\
\hline Treated with Memantine & 20 & 11 & 9 \\
\hline \multicolumn{4}{|l|}{ Comorbidity } \\
\hline Hypertension & 10 & 3 & 7 \\
\hline Ischemic heart disease & 5 & 3 & 2 \\
\hline Diabetes type 2 & 6 & 3 & 3 \\
\hline Depression (in remission) & 7 & 3 & 4 \\
\hline \multicolumn{4}{|l|}{ Marital status } \\
\hline Widow/widower & 22 & 11 & 11 \\
\hline Married & 8 & 4 & 4 \\
\hline Single & 2 & 1 & 1 \\
\hline \multicolumn{4}{|l|}{ Education } \\
\hline Primary & 12 & 8 & 4 \\
\hline Vocational & 6 & 3 & 3 \\
\hline Secondary & 10 & 5 & 5 \\
\hline Higher & 4 & 0 & 4 \\
\hline
\end{tabular}

In the active group of participants with moderate dementia (MMSE 11-18), the cognitive deficits increased (Wilcoxon test $p=0.040$, test power $63 \%$ ).

In 27 patients with LOAD a statistically significant deterioration in the MoCA scale was found in both study subgroups (active and inactive; decrease from 14 to 13 points, $p=0.036$, test power $52 \%$ ). There was a statistically significant decrease from 15 to 14 points in the MoCA scale in the active group ( $p=0.020$, test power $75 \%$ ), but not in the inactive group of women with LOAD. No statistically significant differences were found in the remaining groups.

\section{DISCUSSION}

The aim of the study was to determine whether moderate exercise in the form of Nordic walking, taken over the period 3 months, would improve the general functioning and cognitive functions of people with mild and moderate $\mathrm{AD}$.
There were no statistically significant differences between the ADL measurements at the beginning and the end of the study in the entire active and inactive groups, but deterioration was found in both groups of men. The decrease in ADL scores was also found in the group of men with LOAD. These results would be consistent with the results obtained in a 3-month study of 82 patients with $\mathrm{AD}$, conducted by Roach et al. [19], which consisted of regular walks for 20 minutes a day under the supervision of caregivers. Different results were obtained by Holthoff et al. [20] - no progression of ADL assessed in the ADL scale was observed in the exercising participants at weeks 12 and 24, as opposed to the control group, in which the ADL result deteriorated. Due to the progressive nature of the disease, the lack of progression in comparison to the control group should be treated as a positive effect of the undertaken activity. Similar results were obtained by Vidoni et al. [21]. During the 6-month study, the active group showed an increase of $1 \%$ in the ADL 
score, while the control group showed an $8 \%$ decrease. No such connection was found in the present study; perhaps a longer or more intense training would be necessary to observe a link of this kind.

Rao et al. [22] reviewed 6 studies on exercise involving the total of 446 people with mild to moderate dementia, lasting from 3 to 12 months, in which the ADL scale was the primary research tool. It was found that the disease progression was inhibited in physically active people while progress was observed in the control group. The authors rated the overall effectiveness of aerobic exercise as significant. The best results were achieved by short programs lasting 3 months, promoting more vigorous walks four times a week for 30 minutes [14, 15]. Patient cooperation was found to be good, which was influenced by the involvement of caregivers in the exercise. In the cited study, the tolerance of aerobic exercise in patients was assessed as excellent. The study was very similar to the one presented in terms of duration, severity, form of PA, and its control. The positive impact of physical activation programs continued even for two years after their completion. In the 24-week RCT [20] of people with mild or moderate $\mathrm{AD}$, after 12 weeks a significant difference in $\mathrm{ADL}$ scores was shown between the active and passive groups the active group maintained its performance unchanged, while the disease progressed in the inactive group.

Concerning the above, it could be expected that the time and intensity of training specified in the protocol of the presented study will allow to determine the possible impact of physical activity on the general functioning and cognitive performance of patients. As a side note, it can be observed that the improvement of the physical condition itself may contribute to a certain extent to better ADL results because several areas of activity tested with the use of this measuring tool depend indirectly on physical fitness and motor coordination. A fairly simple form of activity recommended in the presented study was to minimize the impact of the independent variable on learning other skills, which could have happened in the case of another form of activity, used in another previously cited study [23].

The results of the present study do not support the hypothesis that increasing physical activity improves the overall functioning of $\mathrm{AD}$ patients.

No statistically significant differences were found between the MoCA measurements at the beginning and at the end of the present study, neither was it observed in the active and inactive or gender-dependent groups. Cognitive decline was found in some active subgroups, including active women with LOAD and the entire subgroup of active participants with moderate dementia. Cognitive decline was also observed in the entire group of people with LOAD. There was no such decrease in the entire subgroup with moderate or mild dementia (regardless of activity). Lamb et al. [13] described cognitive deficits in people with $\mathrm{AD}$ after 4 months of PA. The deteriora- tion of the condition of the people in the subgroup with the LOAD (they constituted the vast majority of the study participants) is quite unusual, as the LOAD dynamics are usually lower than in the EOAD. Gender-related differences in the influence of aerobic exercise on cognitive functions were described in the study by Barha et al. [24], although the results obtained were different to those demonstrated in the present study - an improvement was noted in the group of active women.

Friedman and Tappen [25] showed that even short and light training (10 weeks and 30 minutes of walking, 3 times a week) can improve verbal skills. According to one meta-analysis [1], even a four-week training session can improve the cognitive functions of people with dementia and MCI. Santoz-Lozano et al. [5] drew similar conclusions: 40 -minute training at $70 \%$ of the maximum heart rate of cycling 3 times a week for 3 months improved the MMSE results in people with mild AD. Yang et al. [26] compared the results achieved by people with mild to severe $A D$, aged 50 to 80 years, who underwent 3-month aerobic training with the results of people who only received education about a healthy lifestyle. The group of exercisers ( 25 people) obtained statistically better results in the MMSE, neuropsychiatric inventory, and the scale testing the quality of life of people with $\mathrm{AD}$, while the results of the non-exercising group showed a further decrease in their cognitive performance. Training with $70 \%$ of a maximum heart rate consisted of 40 minutes of riding a stationary bike 3 times a week for 3 months. The intensity of the training was comparable to that used in this study.

The limitation of the presented study was its quasi-experimental nature. The assessment of the intensity and regularity of physical activity was based on the notes of the caregivers. It is difficult to exclude that some people in the active group exercised less intensively than recommended or declared. As the participants and their guardians were most often elderly, it was not planned to equip them with devices that would objectify the degree of physical activity. Being aware of the above limitations, the independent variable was defined on a nominal scale consisting of two levels: active and inactive. In the light of recent findings, the intensity and duration of training recommended in the present study were slightly lower than those currently defined as potentially effective in slowing down the impact of the underlying disease on cognitive functions $[27,28]$.

The psychometric assessment was made by a person who knew the participant's declaration as to the nature of participation in the study, and the same person classified the respondents to the active or passive group. The small sample size resulted in a lower statistical quality of the collected data. The heterogeneity of the study group in terms of somatic diseases was another limitation, which cannot be, however, eliminated in the population of patients with dementia. The study population also differed in 
terms of pharmacotherapy, the severity of the underlying disease, and the type of the disease ( 5 subjects with EOAD, 27 with LOAD). Males accounted for 6 out of 32 study participants, which also did not correspond to the gender distribution in the general population of patients.

In the light of recent reports on the influence of physical activity on the course of AD, the lack of BDNF Val66Met genotype determination may be a significant limitation in the interpretation of the results. People with the Val/Met genotype benefit less from PA than those with the $\mathrm{Val} / \mathrm{Val}$ genotype. In the analysis of 114 cases of mentally healthy men and women aged 60 years and older by Brown et al. [29], brain volumes were correlated with the levels of physical activity declared by the respondents. In Val/Val homozygotes, higher levels of physical activity were associated with greater volumes of the hippocampus and temporal lobes, while in Met allele carriers it was associated with smaller temporal lobe volumes.

Overall, regular and moderate physical activity did not improve the condition of patients with mild to moderate Alzheimer's disease, both in terms of overall functioning and cognition. Overall functioning deteriorated in both groups of men regardless of physical activity. There were no differences between men and women and between the active and inactive groups - neither at the beginning nor at the end of the study.

\section{Conflict of interest/Konflikt interesu}

Absent./Nie występuje.

Financial support/Finansowanie

Absent./Nie występuje.

\section{References/Piśmiennicłwo}

1. Heyn P, Abreu BC, Ottenbacher KJ. The effects of exercise training on elderly persons with cognitive impairment and dementia: a meta-analysis. Arch Phys Med Rehabil 2004; 85: 1694-1704.

2. Du Z, Li Y, Li J, Zhou C, Li F, Yang X. Physical activity can improve cognition in patients with Alzheimer's disease: a systematic review and meta-analysis of randomized controlled trials. Clin Interv Aging 2018; 13: 1593-1603.

3. Jia RX, Liang JH, Xu Y, Wang YQ. Effects of physical activity and exercise on the cognitive function of patients with Alzheimer disease: a meta-analysis. BMC Geriatr 2019; 19: 181.

4. Ströhle A, Schmidt DK, Schultz F, Fricke N, Staden T, Hellweg R, et al. Drug and Exercise Treatment of Alzheimer Disease and Mild Cognitive Impairment: A Systematic Review and Meta-Analysis of Effects on Cognition in Randomized Controlled Trials. Am J Geriatr Psychiatry 2015; 23: 1234-1249.

5. Santos-Lozano A, Pareja-Galeano H, Sanchis-Gomar F, Quindós-Rubial M, Fiuza-Luces C, Cristi-Montero C, et al. Physical activity and Alzheimer disease: a protective association. Mayo Clin Proc 2016; 91: 999-1020.

6. Yu JT, Xu W, Tan CC, Andrieu S, Suckling J, Evangelou E, et al. Evidence-based prevention of Alzheimer's disease: systematic review and meta-analysis of 243 observational prospective studies and 153 randomised controlled trials. J Neurol Neurosurg Psychiatry 2020; 91: 1201-1209.

7. Sabia S, Dugravot A, Dartigues JF, Abell J, Elbaz A, Kivimäki M, et al. Physical activity, cognitive decline, and risk of dementia: 28-year follow-up of Whitehall II cohort study. BMJ 2017; 357: j2709.

8. Tan ZS, Spartano NL, Beiser AS, DeCarli C, Auerbach SH, Vasan RS, et al. Physical activity, brain volume, and dementia risk: The Framingham Study. J Gerontol A Biol Sci Med Sci 2017; 72: 789-795.

9. Blondell SJ, Hammersley-Mather R, Veerman JL. Does physical activity prevent cognitive decline and dementia? A systematic review and meta-analysis of longitudinal studies. BMC Public Health 2014; 14: 510.

10. Sink KM, Espeland MA, Castro CM, Church T, Cohen R, Dodson JA, et al. LIFE Study Investigators. Effect of a 24-month physical activity intervention vs health education on cognitive outcomes in sedentary older adults: The LIFE randomized trial. JAMA 2015; 314: 781-790.

11. Young J, Angevaren M, Rusted J, Tabet N. Aerobic exercise to improve cognitive function in older people without known cognitive impairment. Cochrane Database Syst Rev 2015; 22: CD005381.

12. Frederiksen KS, Gjerum L, Waldemar G, Hasselbalch SG. Effects of physical exercise on Alzheimer's disease biomarkers: a systematic review of intervention studies. J Alzheimers Dis 2018; 61: 359-372.

13. Lamb SE, Sheehan B, Atherton N, Nichols V, Collins H, Mistry D, et al. DAPA Trial Investigators. Dementia And Physical Activity (DAPA) trial of moderate to high intensity exercise training for people with dementia: randomised controlled trial. BMJ 2018; 361: k1675. 
14. Santana-Sosa E, Barriopedro MI, López-Mojares LM, Pérez M, Lucia A. Exercise training is beneficial for Alzheimer's patients. Int J Sports Med 2008; 29: 845-850.

15. Vreugdenhil A, Cannell J, Davies A, Razay G. A community-based exercise program to improve functional ability in people with Alzheimer's disease: a randomized controlled trial. Scand J Caring Sci 2012; 26: 12-19.

16. Galasko D, Bennett D, Sano M, Ernesto C, Thomas R, Grundman M, et al. An inventory to assess activities of daily living for clinical trials in Alzheimer's disease. The Alzheimer's Disease Cooperative Study. Alzeimer Dis Assoc Disord 1997; 11 Suppl 2: S33-S39.

17. Nasreddine ZS, Phillips NA, Bedirian V, Charbonneau S, Whitehead V, Collin I, et al. The Montreal Cognitive Assessment, MoCA: A brief screening tool for mild cognitive impairment. J Am Geriatr Soc 2005; 53: 695-699.

18. Magierska J, Magierski R, Fendler W, Kłoszewska I, Sobów TM. Clinical application of the Polish adaptation of the Montreal Cognitive Assessment (MoCA) test in screening for cognitive impairment. Neurol Neurochir Pol 2012; 46: 130-139.

19. Roach KE, Tappen RM, Kirk-Sanchez N, Williams CL, Loewenstein D. A randomized controlled trial of an activity specific exercise program for individuals with Alzheimer's disease in long-term care settings. J Geriatr Phys Ther $2011 ; 34: 50-56$.

20. Holthoff VA, Marschner K, Scharf M, Steding J, Meyer S, Koch R, et al. Effects of physical activity training in patients with Alzheimer's dementia: results of a pilot RCT study. PLoS One 2015; 10: e0121478.

21. Vidoni ED, Perales J, Alshehri M, Giles AM, Siengsukon CF, Burns JM. Aerobic exercise sustains performance of instrumental activities of daily living in early-stage Alzheimer's disease. Geriatr Phys Ther 2019; 42: 129-134.

22. Rao AK, Chou A, Bursley B, Smulofsky J, Jezequel J. Systematic review of the effects of exercise on activities of daily living in people with Alzheimer's disease. Am J Occup Ther 2014; 68: 50-56.

23. Henskens M, Nauta IM, van Eekeren MCA, Scherder EJA. Effects of physical activity in nursing home residents with dementia: a randomized controlled trial. Dement Geriatr Cogn Disord 2018; 46: 60-80.

24. Barha CK, Hsiung GR, Best JR, Davis JC, Eng JJ, Jacova C, et al. Sex difference in aerobic exercise efficacy to improve cognition in older adults with vascular cognitive impairment: secondary analysis of a randomized controlled trial. J Alzheimers Dis 2017; 60: 1397-1410.

25. Friedman R, Tappen RM. The effect of planned walking on communication in Alzheimer's disease. J Am Geriatr Soc 1991; 39: 650-654.

26. Yang SY, Shan CL, Qing H, Wang W, Zhu Y, Yin MM, et al. The effects of aerobic exercise on cognitive function of alzheimer's disease patients. CNS Neurol Disord Drug Targets 2015; 14: 1292-1297.

27. Gomes-Osman J, Cabral DF, Morris TP, McInerney K, Cahalin LP, Rundek T, et al. Exercise for cognitive brain health in aging: A systematic review for an evaluation of dose. Neurol Clin Pract 2018; 8: 257-265.

28. McNamara D. Optimal exercise dose for better cognition determined. Medscape June 012018.

29. Brown BM, Bourgeat P, Peiffer JJ, Burnham S, Laws SM, Rainey-Smith SR, et al. Influence of BDNF Val66Met on the relationship between physical activity and brain volume. Neurology 2014; 83: 1345-1352. 